\title{
Temperature Defects on Compressor Housing Die Casting Method
}

\author{
DR. Ch. S. Naga Prasad \\ Professor \& Principal, Department of Mechanical Engineering, GIITS Engineering College, Aganampudi, \\ Visakhapatnam (DT), A.P, India
}

\begin{abstract}
With the increasing power of computer hardware and software, computational simulation and visualization are becoming increasingly important tools to understand and improve industrial processes, such as metal casting. Computer-aided visualization is increasing the power of all of the tools available to the solidification process engineer, including previous literature, mathematical modeling, laboratory experimentation, and online measurement of the casting processes. Die casting is a metal casting process that is characterized by forcing molten metal under high pressure into a mold cavity. In this thesis, main emphasis will be on the optimization of process parameters in High pressure die casting. A case study of compressor housing is considered where the flow simulations results are analyzed for optimization. An analytical approach is discussed by using software Ansys Fluent to analyze the behavior of molten metal at different stages of time by observing the results of temperature variations, pressure variations and liquid fractions by applying the input parameters molten metal temperature, die temperature and velocity of flow. The model of the component with spreader design, runner design, gate location and overflows is done in 3D modeling software Pro/Engineer.
\end{abstract}

Keywords: Die casting, metal casting process, spreader design, runner design, gate location.

\section{INTRODUCTION}

Die casting is a manufacturing process that can produce geometrically complex metal parts through the use of reusable molds, called dies. The die casting process involves the use of a furnace, metal, die casting machine, and die. The metal, typically a non-ferrous alloy such as aluminum or zinc, is melted in the furnace and then injected into the dies in the die casting machine. There are two main types of die casting machines - hot chamber machines (used for alloys with low melting temperatures, such as zinc) and cold chamber machines (used for alloys with high melting temperatures, such as aluminum). The differences between these machines will be detailed in the sections on equipment and tooling. However, in both machines, after the molten metal is injected into the dies, it rapidly cools and solidifies into the final part, called the casting. The steps in this process are described in greater detail in the next section.

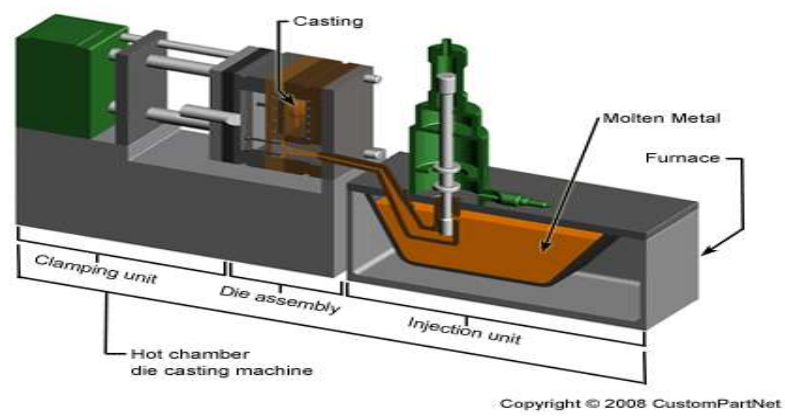

The castings that are created in this process can vary greatly in size and weight, ranging from a couple ounces to 100 pounds. One common application of die cast parts are housings - thin-walled enclosures, often requiring many ribs and bosses on the interior. Metal housings for a variety of appliances and equipment are often die cast. Several automobile components are also manufactured using die casting, including pistons, cylinder heads, and engine blocks. Other common die cast parts include propellers, gears, bushings, pumps, and valves.

\section{LITERATURE REVIEW}

In the paper by Mohammad Sadeghi, etal ${ }^{[1]}$, die temperature in high-pressure die casting of A380 alloy is optimized by experimental observation and numerical simulation. Ladder frame (one part of the new motor EF7) with a very 


\section{IARJSET

complicated geometry was chosen as an experimental sample. Die temperature and melt temperature were examined to produce a sound part. Die temperatures at the initial step and the final filling positions were measured and the difference between these values was calculated. ProCAST software was used to simulate the fluid flow and solidification step of the part, and the results were verified by experimental measurements. It is shown that the proper die temperature for this alloy is above $200^{\circ} \mathrm{C}$.

In the paper by A. P.Wadekar, etal ${ }^{[7]}$, Gravity die casting is used to manufacture the complex metal components where there is a need for high structural integrity. The casting defects that are caused by molten metal include air entrapment, porosity, and shrinkage. But the control of casting defects has been based on the experience of the foundry engineers.

This paper describes these defects in casting with the help of computer aided simulation. These are demonstrated using a simple two dimensional example which contains the essential features of compressor housing. The computer simulations have been carried out to analyze the flow of molten metal .

The, flow ranging in 0.7 to $1 \mathrm{kgs} / \mathrm{s}$ in $5 \mathrm{~mm}$ thin wall casting was examined to find the optimal parameters for the diecasting process. The results for compressor housing body are obtained by simulation and required corrective measures are implemented in actual component. It is seen that the most important physical situation during a casting process is solidification by cooling its surroundings where numerous defects can generate through changes during the heat transfer process from liquid form to a solid form. The design, simulation, analysis and testing work is carried at Spark Minda Co. Ltd, Chakan, Pune.

\section{PROBLEM DESCRIPTION}

Most of the die casting industries faces the problem of casting defects caused due to improper design of dies, or due to incorrect parameters such as injection pressure, cycle time, cooling circuits and other such parameters.

The defects after the manufacturing and production is a loss to the company as it leads to the rework of die design and manufacturing which taken again more time thereby increasing the overall lead time. If the lead time increases, there is a possibility of customer dissatisfaction for further collaboration.

In order to rectify these problems, in this thesis an analytical approach is discussed by using software Ansys Fluent to analyze the behavior of molten metal at different stages of time by observing the results of temperature variations, pressure variations and liquid fractions by applying the input parameters are molten metal temperature, die temperature and velocity of flow. The model of the component with spreader design, runner design, gate location and overflows is done in $3 \mathrm{D}$ modeling software Creo.

\section{INTRODUCTION TO CAD/CAE}

Computer-aided design (CAD), also known as computer-aided design and drafting (CADD), is the use of computer technology for the process of design and design-documentation.

\subsection{INTRODUCTION TO PRO-ENGINEER}

Pro/ENGINEER Wildfire is the standard in 3D product design, featuring industry-leading productivity tools that promote best practices in design while ensuring compliance with your industry and company standards. Integrated Pro/ENGINEER CAD/CAM/CAE solutions allow you to design faster than ever, while maximizing innovation and quality to ultimately create exceptional products.

\section{Different modules in pro/engineer}

Part design, Assembly, Drawing\& Sheet metal.

\subsection{INTRODUCTION TO FINITE ELEMENT METHOD:}

Finite Element Method (FEM) is also called as Finite Element Analysis (FEA). Finite Element Method is a basic analysis technique for resolving and substituting complicated problems by simpler ones, obtaining approximate solutions Finite element method being a flexible tool is used in various industries to solve several practical engineering problems. In finite element method it is feasible to generate the relative results.

\section{RESULTS AND DISCUSSIONS}

5.1. Models of base plate of load cell using pro-e wildfire 5.0: The base plate of load cell is modeled using the given specifications and design formula from data book. The base plate outer casing body profile is sketched in sketcher. 
Base plate of load cell 3D model

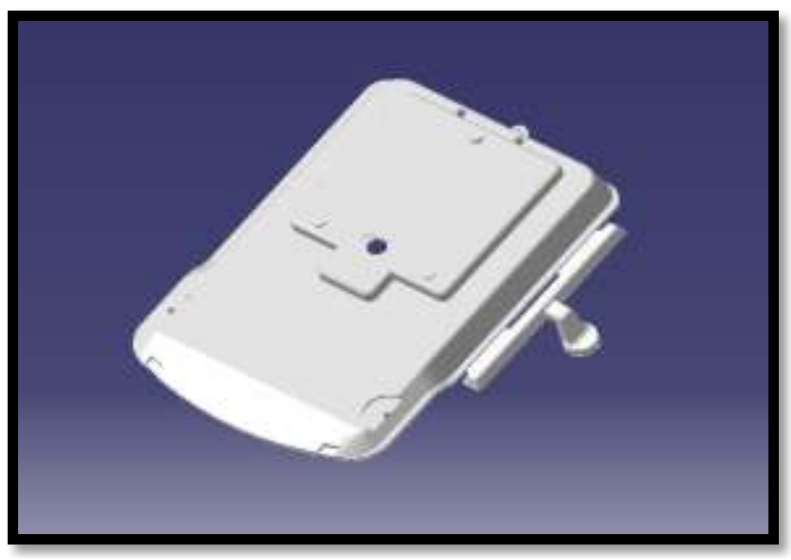

\subsection{CFD ANALYSIS OF COMPRESSOR HOUSING}

\section{Static temperature}

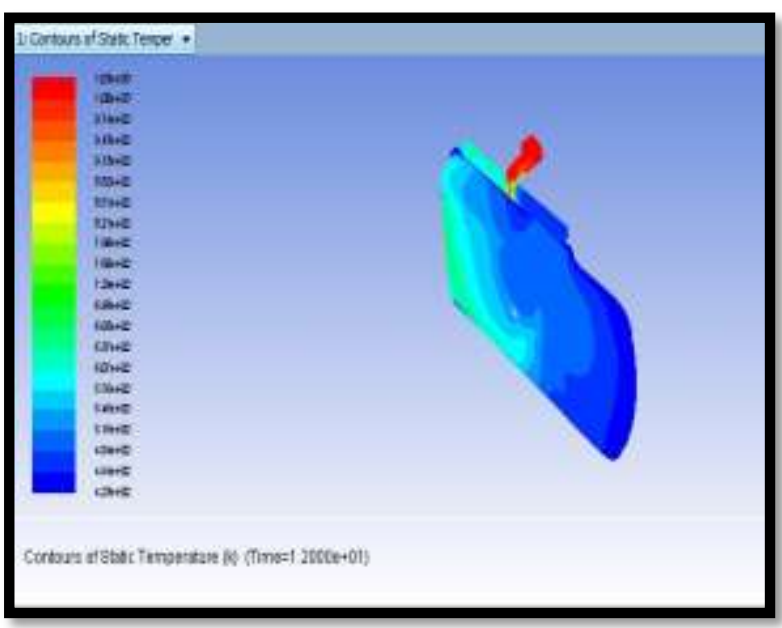

Pressure

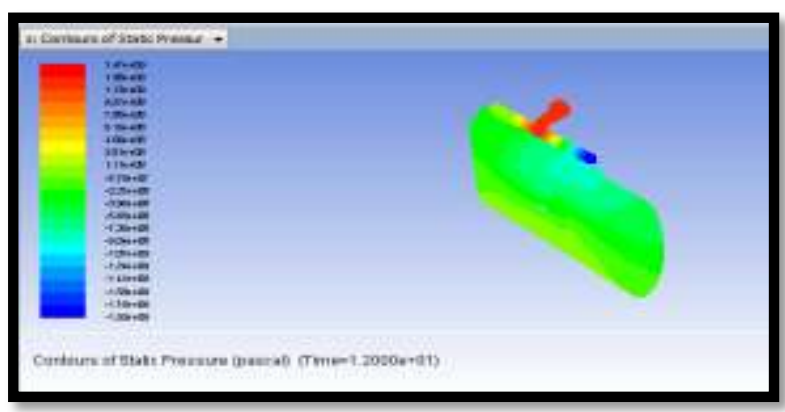

Liquid fraction

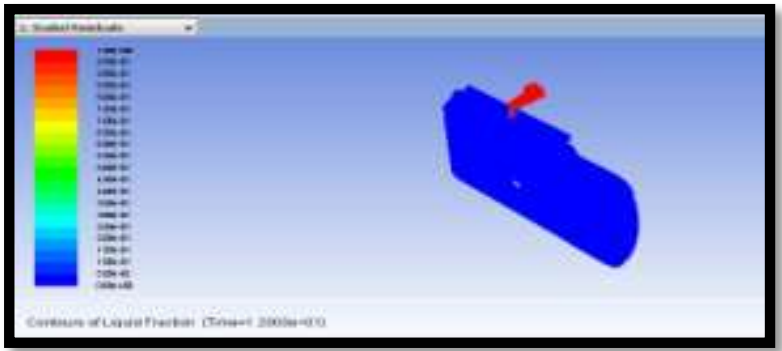


International Advanced Research Journal in Science, Engineering and Technology ISO 3297:2007 Certified

Vol. 4, Issue 5, May 2017

\section{RESULTS AND DISCUSSIONS}

CFD ANALYSIS RESULT TABLE

\begin{tabular}{|c|c|c|c|c|c|}
\hline FILLING TIME (Secs) & Die Temperature (K) & \multicolumn{2}{|c|}{ Static Temperature (K) } & Pressure (PA) \\
\hline & & Min & Max & $\Delta$ T & \\
\hline \multirow{3}{*}{12} & 393 & 423 & 1003 & 580 & $1.47 \mathrm{e}^{9}$ \\
\cline { 2 - 6 } & 423 & 423 & 1003 & 580 & $1.25 \mathrm{e}^{9}$ \\
\cline { 2 - 6 } & 523 & 523 & 1004 & 481 & $3.66 \mathrm{e}^{7}$ \\
\hline \multirow{3}{*}{10} & 393 & 393 & 1006 & 613 & $2.08 \mathrm{e}^{9}$ \\
\cline { 2 - 6 } & 423 & 419 & 1003 & 584 & $8.58 \mathrm{e}^{7}$ \\
\cline { 2 - 6 } & 523 & 458 & 1003 & 545 & $4.05 \mathrm{e}^{7}$ \\
\hline \multirow{3}{*}{8} & 393 & 293 & 1003 & 710 & $2.44 \mathrm{e}^{9}$ \\
\cline { 2 - 6 } & 423 & 392 & 1003 & 611 & $2.93 \mathrm{e}^{8}$ \\
\cline { 2 - 6 } & 523 & 522 & 1003 & 481 & $8.64 \mathrm{e}^{7}$ \\
\hline
\end{tabular}

GRAPHS
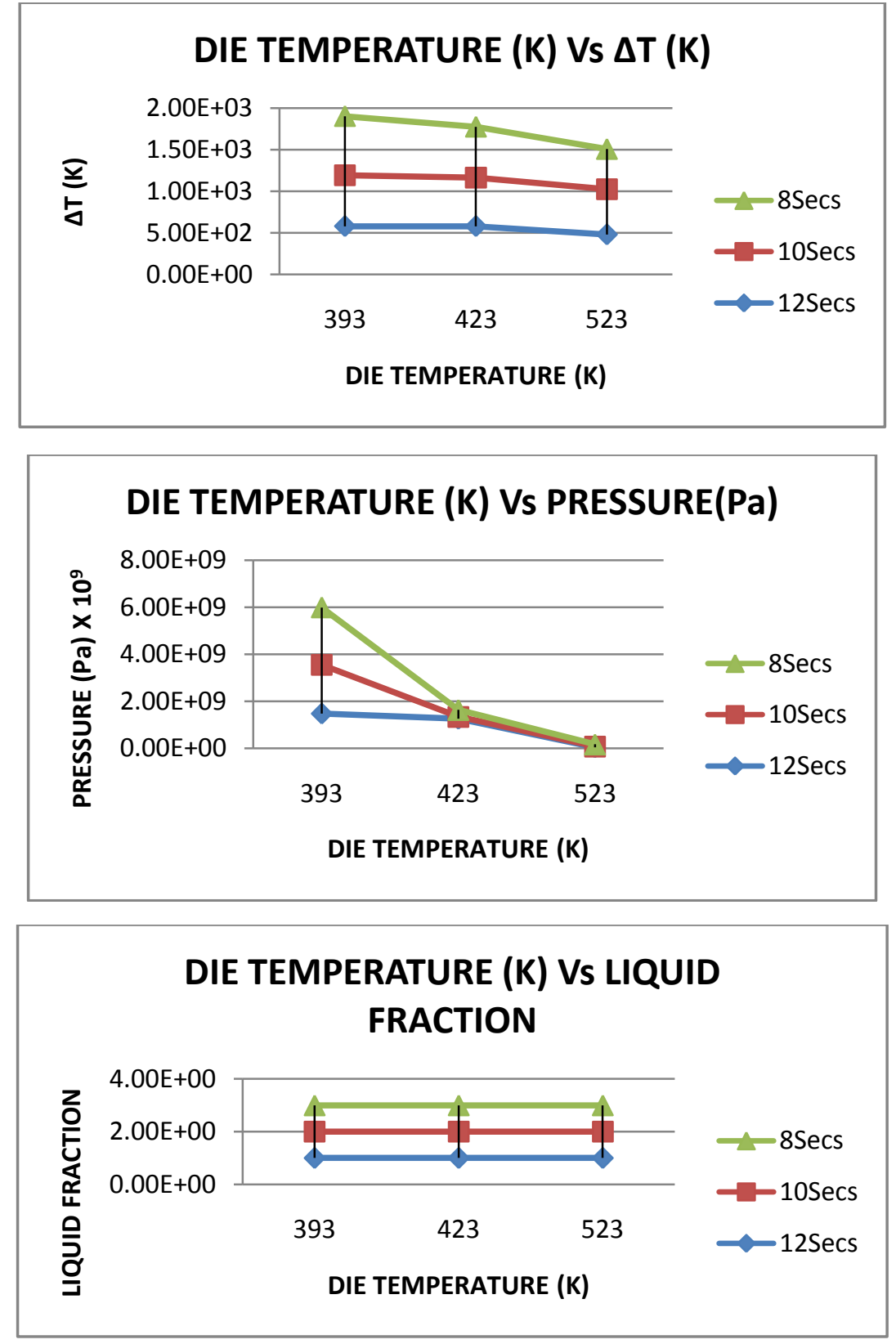


\section{IARJSET

\section{CONCLUSION}

In this thesis, the optimum filling time, injection pressure and die temperature for better solidification of the filling material are analyzed by taking the input parameters molten metal temperature, velocity at spreader, injection time and die temperature.

Solidification analysis is done in Ansys CFD.

From the results, the following conclusions can be made:

The better solidification occurs at 8 secs injection time, $2.44 \mathrm{e}^{9} \mathrm{~Pa}$ pressure and $393^{0} \mathrm{C}$ die temperature. Solidification of molten metal at high pressure and less die temperature increases the mechanical properties such as impact strength, tensile strength and hardness.

These parameters can be applied practically in experimental investigation. From this thesis, trail and error methods in manufacturing process of pressure die casting die methods can be avoided thereby reducing total cycle time and also material wastage in manufacturing process. The problems faced in the casting industry can be rectified by this method.

\section{REFERENCES}

1. Mohammad Sadeghi and Jafar Mahmoudi, Experimental and Theoretical Studies on the Effect of Die Temperature on the Quality of the Products in High-Pressure Die-Casting Process, Advances in Materials Science and Engineering, Volume 2012 (2012), Article ID 434605, 9 pages

2. Rajesh Rajkolhe, J. G. Khan, Defects, Causes and Their Remedies in Casting Process: A Review, International Journal of Research in Advent Technology, Vol.2, No.3, March 2014, E-ISSN: 2321-9637

3. Bodhayana M.R., N Ramesha, Molten metal flow analysis of housing component, IJRET: International Journal of Research in Engineering and Technology, eISSN: 2319-1163, ISSN: 2321-7308

4. Quang-Cherng Hsu and Anh Tuan Do, Minimum Porosity Formation in Pressure Die Casting by Taguchi Method, Mathematical Problems in Engineering Volume 2013 (2013), Article ID 920865, 9 pages

5. Sandeep.V. Chavan, Rajeev.K.Tavildar, Casting Defect Analysis and Optimization Using Computer Aided Casting Simulation Technique, International Journal of Innovative Research in Science, Engineering and Technology (An ISO 3297: 2007 Certified Organization), Vol. 3, Issue 7, July 2014, ISSN: 2319-8753

6. Javed Gulab Mulla, Prof. V.V. Potdar, Swapnil S. Kulkarni, Mulla, Investigating die casting process parameters to identify the optimized levels using taguchi methods for Design of Experiment (DOE), International Journal of Advanced Engineering Research and Studies, ISSN2249-8974

7. A. P.Wadekar, B.A.Ahir1, L.G.Navale, S.H.Gawande, R. Mathai, R.Mishra, Die Casting Defect Analysis \& Experimental Validation for Compressor Housing, IOSR Journal of Mechanical and Civil Engineering (IOSR-JMCE), ISSN(e) : 2278-1684, ISSN(p) : 2320-334X, PP : 5561

8. Ferhathullah, Hussainy, M. Viquar Mohiuddin, P. Laxminarayana, A. Krishnaiah, S. Sundarrajan, A Practical approach to eliminate defects in gravity die cast Al-alloy casting using simulation softwares, JRET: International Journal of Research in Engineering and Technology, eISSN: 2319-1163, ISSN: 2321-7308

9. M. MUHIC, J. TUSEK, F. KOSEL, D. KLOBCAR, M. PLETERSKI, Thermal fatigue cracking of die-casting dies, ISSN 0543-5846, METABK 49(1) 9-12 (2010)

10. B. Vijaya Ramnath, C.Elanchezhian, Vishal Chandrasekhar, A. Arun Kumar, S. Mohamed Asif, G. Riyaz Mohamed, D. Vinodh Raj, C .Suresh Kumar, Analysis and Optimization of Gating System for Commutator End Bracket, Procedia Materials Science 6 ( 2014 ) 1312 - 1328

\section{BIOGRAPHY}

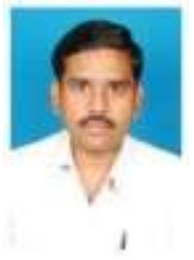

DR. Ch. S. Naga Prasad received his M.Tech Degree on Heat power Refrigerator and AC from JNTU, Anantapur in 2002 and Ph.D on IC Engines (Thermal Engg) from JNTU, Hyderabad in 2011. He is currently working as Professor \& Principal in Gonna Institute of Information Technology and sciences, Aganampudi, Visakhapatnam, A.P, INDIA. 